\title{
TEACHERS' VOICES ON THE 2013 CURRICULUM FOR ENGLISH INSTRUCTIONAL ACTIVITIES
}

\author{
Maulidia Rachmawati Nur \\ Ibn Khaldun University, Bogor, West Java \\ maulidia.rnur@gmail.com \\ Ahmad Madkur \\ STAIN Jurai Siwo Metro, Lampung \\ madzkur_ahmad@yahoo.com
}

\begin{abstract}
Curriculum is undoubtedly an inseparable part of education. In Indonesia, education curriculum has already undergone several changes. Among others, the newly introduced and implemented one is called Curriculum 2013 (K-13). Involving a "scientific approach", this curriculum is expected to answer both the needs and the challenges to improve the quality of education in Indonesia. Nevertheless, the implementation of this curriculum gives birth to some pros and cons. The present paper is aimed at providing a picture of challenges, opportunities and teachers' perception on the use of this curriculum in English teaching. The data were collected through in-depth interview to six English teachers in six pilot schools in Bogor and Lampung. The analysis shows that most teachers accepted the curriculum. However, according to them, the curriculum should be evaluated and further developed.
\end{abstract}

Key Words: 2013 curriculum, English teaching, teachers' perceptions

\begin{abstract}
ABSTRAK
Kurikulum merupakan bagian yang tidak terpisahkan dari pendidikan. Di Indonesia, kurikulum pendidikan telah mengalami beberapa perubahan, yang terbaru adalah Kurikulum 2013 (K-13). Menggunakan konsep "pendekatan ilmiah", kurikulum ini diharapkan dapat menjawab kebutuhan dan tantangan untuk meningkatkan kualitas pendidikan di Indonesia. Akan tetapi, pelaksanaan kurikulum ini menimbulkan banyak pro dan kontra. Tulisan ini bertujuan untuk memberikan gambaran singkat mengenai tantangan, peluang dan persepsi guru terhadap penggunaan kurikulum ini dalam pengajaran bahasa Inggris. Data dikumpulkan melalui wawancara mendalam kepada 6 guru bahasa Inggris di 6 sekolah percontohan (pilot school). Hasil analisa menunjukkan bahwa hampir semua guru bisa menerima diberlakukannya kurikulum ini. Meski demikian, menurut mereka, kurikulum 2013 ini perlu dievaluasi dan dikembangkan lebih lanjut.
\end{abstract}

Kata Kunci: Kurikulum 2013, pengajaran bahasa Inggris, persepsi guru 


\section{INTRODUCTION}

Curriculum is one of the main education components stated on the Indonesia Education Act number 20/2003. The general statements of the constitution define curriculum as a set of plans and arrangements covering education goals, contents, learning materials, and learning methods intended to serve as the guidelines in implementing the teaching and learning process to achieve the goals that have been set. Therefore, curriculum has a very important role in providing fundamental reference concerning what students should learn and achieve.

To start the discussion, it is important to further clarify what we understand about curriculum. Some experts consider that curriculum and syllabus are two interchangeable concept. However, some others distinguish curriculum from syllabus. Yalden (1987, p. 18), for instance, stated:

The curriculum includes the goals, objectives, content, processes, resources, and means of evaluation of all the learning experiences planned for pupils both in and out of school and community through classroom instruction and related program.
In other words, curriculum is a set of instructional activities consisting of several important elements namely purpose, content, procedures, resources and tool of assessment. It does not only cover the planning of both school and out of school activities. This definition implies that curriculum is broader than a syllabus and that a syllabus is part of curriculum. Dubin and Olshtain (1986, p. 34-35) define a curriculum as "a broad description of general goals by indicating an overall educationalcultural philosophy which applies across subjects", whereas a syllabus as "a more detailed and operational statement of teaching and learning elements, which translates the philosophy of the curriculum into a series of planned steps leading towards more narrowly defined objectives.". In short, curriculum serves in the level of paradigm on which the educational practice is based. Meanwhile, syllabus is focused on realizing what is designed in curriculum. Therefore, it can be said that syllabus is a part of curriculum.

The aforementioned notion is in line with Krahnke (1987) who states that curriculum includes syllabus, but not vice versa. Furthermore, according to Celce-Murcia (1991, p. 9), a syllabus is "an inventory of things the learner should master." This inventory is sometimes presented in a recommended sequence and is made 
use of in designing courses and teaching materials. The type of syllabus employed very often influences the type of approach and method adopted. Similarly, the approach or method tends to change along with the revision of the syllabus (Cahyono \& Widiati, 2011).

Content is usually considered as one of the important aspects in designing syllabus (Krahnke, 1987). However, in practice some teaching syllabus generally includes behavioral or learning objectives for students, specifications of how the content will be taught and strategies to evaluate them. The content in this case concerns "which definition of language will be assumed by the instruction and what linguistic content will form the basis and organization for the instruction" (Krahnke, ibid, p. 2). This means that in the making of syllabus, content, method, and assessment should be involved.

Related to the execution of curriculum, the teacher is the key point in the development of curriculum for teachers is the spearhead implementation on the ground. This is in line with Murray Print (1993) who views that teachers are required to implement the curriculum, to adapt the curriculum with school characteristics and local needs, to design curriculum and to conduct curriculum research. In other words, it could be considered that curriculum development starts from the class. Therefore, teachers should have a creative idea and examine the curriculum in class as an important phase and as an element of the overall administrative support.

Due to the vital role of teachers in the execution of curriculum in classroom, it is urgent that their opinions, whether it is pro or con, is considered. Various suggestions coming from different teachers can enrich and give us wider perspectives to see the real implementation of the 2013 curriculum. Therefore, this paper is intended to investigate whether the teachers agree or disagree on the new curriculum and what are the challenges and opportunities based on the teachers' perceptions.

\section{THE DEVELOPMENT OF THE INDONESIAN CURRICULA}

In Indonesian context, according to Dit. PSMP (Direktorat Pembinaan Sekolah Menengah Pertama/ Directorate of Junior High School Development, 2009), the Indonesian government has officially issued different curricula. Up to now there have been 10 curricula, which development will be explained in this section.

The first curriculum, Leer Plan (Rencana Pelajaran) was issued in 1947. 
The curriculum involved a political view to reject the implementation of the Dutch curriculum. The principles of education was decided by Pancasila. Because the situation was still in revolution war, the curriculum had just been officially implemented in 1950. The Leer plan only contained of two primary aspects, i.e. list of lesson with its indication of length of time and outlines of teaching. In 1952, this curriculum was then revised by the second curriculum called Unraveled Leer Plans (Rentjana Pelajaran Terurai) 1952. The curriculum concerned on how to relate the materials with everyday activities.

In 1964, the government revised again the curriculum system with the so-called Educational Plan (Rentjana Pendidikan) 1964. The main focus of this curriculum was to equip Indonesian people with academic knowledge since the level of elementary school. This curricululm preached Pancawardhana, which included the development of creativity, sense, initiative, work and moral.

The fourth was the 1968 Curriculum, which belonged to separate-subject curriculum, whereby the subject content was logically and systematically sequenced, and each subject was separated from others. Concerning the English instruction, the Decree of the Minister of Education
Number 096/19679, stated that the language skills to be developed were reading, listening, writing, and speaking (Huda, 1999). However more emphasis was given to the development of reading skill, whereas that of speaking skill was given the least priority.

The above curriculum was revised through the establishment of the next curriculum, i.e. the 1975 Curriculum. In this curriculum, the teaching of English was aimed both at developing the four language skills (listening, speaking, reading, and writing). Although the emphasis was still on reading skill development, the teaching of English was also aimed at equipping students with the language components (grammar, pronunciation, and vocabulary), with more stress on grammar mastery (Tjokrosujoso, et al., cited in Cahyono \& Widiati, 2011). Furthermore, this concept was revised with the 1984 curriculum, where the teaching of English aimed at putting back the true goals of learning English, which were to achieve, "meaningfulness and communicative functions" (the Ministry of Education and Culture, cited in Huda, 1999).

In 1984, a curriculum intended to complete the 1975 curriculum was made. It was called Student Active Learning/Cara Belajar Siswa Aktif (SAL/CBSA) curriculum. This 
curriculum made the students the subject of learning. It was oriented to instructional purpose, in which the limited time of teaching and learning in classroom should be able to provide learning opportunities for students. This was at the end intended to create effective and beneficial learning opportunities for all students.

The next curriculum was the 1994 curriculum, which offered an idea that English syllabus should be developed by a team in order that adequate subject contents could be ensured in the development of the school curriculum (Dit. PSMP, 2009). The team should consist of specialists in teaching English as a Foreign Language (TEFL), curriculum developer, practicing teachers, and school system authorities (Huda, 1999). Another feature of the 1994 English syllabus was that it consisted of several components. The first was national content, which was implemented nationally. In other words, all students throughout the country should at least achieve the goals in the national content. The second served as enrichment content, which was implemented to students who had achieved the national content. The last one was local content, which was intended to address the regional or local needs of the students in accordance with the local situation.
It is apparent that global changes as well as science and technology advancement appear to influence the curriculum innovations. In line with this, responding to the implementation of the Indonesian Law Number 22/1999 on Regional Autonomy, the government released CompetenceBased Curriulum (CBC) in 2004. The English curriculum, in particular, adopted the schematic representation of communicative competence introduced by Celce-Murcia et al. (as cited in Agustien, 2003).

CBC was generally criticized not to provide opportunity for teachers to get involved in the development of the curriculum. As a consequence, the government attempted to improve the curriculum through the establishment of School-based Curriculum (SBC) or locally called Kurikulum Tingkat Satuan Pendidikan (KTSP) in 2006. This curriculum was developed in response to global as well as local changes and learners' needs, the diversity of Indonesia, the advancement of technology, science, and arts, the need to enforce lifelong learning, and the balance of both the national and the local needs (Cahyono \& Widiati, 2011).

The above explanation on the development of the curriculum shows us that curriculum is not static. Curriuclum could change in response to different conditions and needs. 
Curriculum should serve as one the solutions in addressing various problems that emerge from time to time. What has been done by the government needs to be appreciated even though some parts of the work should be seriously improved.

\section{THE EMERGENCE OF THE 2013 CURRICULUM}

In general, the emergence of the 2013 curriculum (later on in this paper is sometimes referred to as K-13 to avoid repetition) is the reaction to the fact that Indonesia is following the respective years of global world and its problematic issues. Indonesia is working towards the betterment of its education quality, following the competitive challenges of globalization. Not to mention all, the upcoming ASEAN Free Trade Area (AFTA) implies the need for the global competition. For this reason, it is logical that the government improves the quality of the young generation so that they are ready to face both the positive and the negative effects of the globalization.

In relation to the education quality, the study of PISA (Program for International Student Assessment) and TIMSS (Trends in International Mathematics and Science Study) show that Indonesian students have low quality. The reports of both programs show that the students of Indonesia are lack of critical, analytic, and procedural competences. This low competence is likely to be related to the previous curriculum, which focused too much on covering broad content and cognitive aspect, not on the essential aspects that will enable students to be critical and be able to participate in the global world to support Indonesia in the upcoming years. Additionally, the new curriculum also offer the building of character to prepare the students to face various opportunities, which could bring both positive and negative sides to students and society in general. Character education gives the students the knowledge they need to know especially concerning the negative effects of the advancement of technology, science, and art and how they could deal with them properly.

The 2013 curriculum in general have many similarities with its predecessor, KTSP curriculum. However, there are some new features in this curriculum. First, compared to KTSP, there is a concrete assessment in each aspect in the 2013 curriculum, in which indicators are provided to help teachers easily check their students' achievement. Then, specifically referring to the students of senior high school, in the previous curriculum, students select their major in the $11^{\text {th }}$ grade, while in the 2013 curriculum, 
they should select their major in the 10th grade. The next difference is thematic-integrative approach implemented in the level of elementary school. This approach facilitates the elementary students learn according to the theme, which can involve some subjects. Furthermore, the other difference is the deletion of Computer Information Technology or TIK subject. The 2013 curriculum considers TIK subject to be involved in all other subjects as learning media, not as a separate subject.

Due to some changes mentioned above, what is actually expected from this new curriculum? Despite its controversy, curriculum 2013 contains innovations to create better learning practice, which is intended mainly to improve the quality of the students. Different from the previous KTSP curriculum, teachers are not required to develop their syllabus anymore, and therefore they are expected to be more focus on studying and preparing the materials so that they can provide more quality learning opportunities for students. Then, the thematic-integrative approach gives wider chance for the teachers to enrich the materials. Additionally, the students can get broader knowledge. In a bigger paradigm, the curriculum changes which concern on character education are expected to be a new hope for the quality betterment of national education. Furthermore, the character education is directed to give birth to generation with strong character, high integrity of moral and tough mentalspiritual behavior.

\section{ENGLISH TEACHING IN 2013 CURRICULUM}

According to Wachidah (2013), the 2013 English Curriculum seems to be the reactions or correction of the previous curriculum and the reality that has happened. The reality shows that most high-school learners can hardly use English in the real world even for simple purposes. It is also far below the nationally set standards of English Competence. A number of factors appear to account for the problems as the following:

1. Students learn pronunciation, word stressing, and intonation, yet these elements are severely ignored. The coherence among different skills and language components is also untouched. The activities of listening, speaking, reading and writing are not integrated.

2. Students learn too many expressions, not activities.

3. Students focus on grammar and vocabulary, not the texts.

4. Artificial texts are presented in several textbooks, not the real texts. 
5. Reading and writing exercises are given priority, not using the language.

6. The teaching and learning activities are text-book based, which consequently make students not to have maximum learning opportunity to make meanings for real communication purposes in almost all activities in listening, speaking, reading, and writing tasks.

7. The learning process is teacher centered. Students' learning process depends on the teacher's explanation and provision of, practice and homework.

Based on the problems of the previous curriculum, the 2013 English Curriculum is seen much better as it is developed by following these principles:

1. The 2013 English Curriculum is bringing back the true goal of English teaching, that is, "meaningfulness and communicative functions". The final goal of English teaching is the development of communicative competence in the English language. CLT (Communicative Language Teaching) is adopted on the 2013 Curriculum.

2. The 2013 English Curriculum is expected to shift from very teachercentered to more student-centered.
3. Students learn the social function, text structure, and lexicon grammar. Topics are closely related to the students' life at school, home and society.

4. Students learn English by observing, questioning, exploring, associating, and communicating. The processes of observing, questioning, exploring, associating and communicating are expected to promote students to have critical, analytic, investigational, procedural and communicative competences.

5. The teacher plays as a model of language user and language learner.

6. Students use authentic or nearauthentic texts, spoken and written from various sources, including English textbook and textbooks for other subjects.

7. Students are empowered for the availability of texts.

8. Students are expected to learn English interpersonal, transactional, functional communication.

9. Students should learn attitude, knowledge, and skills.

10.The students learn English by activities, real texts, and using the language. 


\section{TEACHER'S ROLE IN CURRICU- LUM IMPLEMENTATION}

Curriculum 2013 is basically a refinement of the previous curriculum. The target of curriculum change is none other than the teacher as the direct implementers in the classroom. While curriculum is the planned program, teachers are the actors that implement the program through teaching and learning process. This is the relationship between teachers, curriculum and learning.

There are several roles that teachers should have in implementing the 2013 curriculum:

1. Teacher as a learning designer

As a professional teacher, he/she designs learning plan which will be conducted in the classroom. The study design is expected to be both structured and practical.

2. Learning Motivator

One of the hardest roles of teacher is maintaining the willingness of students to explore the learning material as much as possible. Motivation, as revealed in many studies, is a very potential factor to make students excited to learn optimally.

3. Learning Mediator

The presence of teachers in the teaching and learning process could serve as an intermediary actor between the sources of learning and students. The teacher presents the subject matter to students' learning and students receive, examine, and discuss the matter so that it becomes theirs. As a mediator, the teacher lays the platform for the teaching and learning process. The teacher interposes something within the environment with which the students interact.

\section{Learning Inspiration}

Teachers become a major source of inspiration for students in managing the subject matter. Thinking and strategy delivered by the teacher will encourage students to learn independently and creatively.

\section{METHOD}

This research used qualitative approach. How English teachers conceive of the implementation of curriculum 2013 and its effect on English teaching was investigated. The participants were 6 English teachers coming from four pilot schools in Bogor and two pilot schools in Lampung. In each of those schools, one English teacher was selected randomly since all English teachers at those school have the same duty in implementing the 2013 curriculum. To gather this data, the participants were asked several questions through in-depth interview. From six types questions in the interview (Patton, cited in Fraenkel \& Wallen, 2008), the kinds of questions 
raised in the interview were about insight, experience and attitude, opinion and assessment, and feeling. For example, "How do you conceive of curriculum 2013?", “What are difficulties you face in implementing it in your classroom activities", "What is your suggestion for the betterment of the curriculum?", "Do you actually agree or disagree on the curriculum change? Why?", and so forth. The result of interview were analyzed using Miles and Huberman model (Miles \& Huberman 1994) by which the data were, reduced, displayed and verified.

\section{FINDINGS AND DISCUSSION}

\section{English Teachers' Perception on the 2013 Curriculum}

As previously explained, to get information about the K-13 implementation, interview was conducted to English teachers at 4 schools in Bogor and 2 schools in Lampung. This section will present each of teachers' opinion about the curriculum. For ethical reason, their names and their schools are made anonymous.

Mrs. NR is an English teacher at state junior high school (SMPN) in Bogor. She is also one of the national instructors of the 2013 curriculum. She thinks that the 2013 curriculum is very good to be implemented. She considers that the concept of active learning, character building, and new paradigm of the 2013 curriculum is very relevant with the challenges faced by Indonesia. She hopes that all the teachers, as the main players of the 2013 curriculum, could feel and read the messages of the emergence of 2013 curriculum, and actively participate to implement in their own field.

The next participant is Mrs. DR, who is an English teacher at a state senior high school (SMUN) in Bogor. She argues that some teachers and schools do not have enough information about the implementation of the 2013 curriculum. In relation to the concept of the 2013 curriculum, she mentions that the process-oriented learning (observing, questioning, collecting information, associating, and communicating) promises the students of Indonesia to be active learners who have critical thinking. She is optimistic in getting involved in the process of the implementation of the 2013 curriculum. She thinks that one of the challenges is to set the interesting learning sources for her students and scoring criteria.

Mr. EK, currently a Senior English Teacher at SMKN in Bogor, supports the 2013 curriculum to be implemented. However, according to him, the scoring criteria are rather complicated. Specifically referring to the teaching of English subject in SMK, he criticizes the 
fact that that General English has been so far given more priority, not the English for specific purposes.

In terms of the scoring criteria, Mr. H, an English Teacher at MTSN in Bogor, and Mrs. SD, an English teacher at MAN in Bogor, argue that the 2013 Curriculum is better. The Scoring criteria do not only focus on cognitive aspect, but also the personality aspect. Process-oriented in learning are given priority.

Different from the above positive opinion, Mr. DA, an English teacher at SMKN 1 Metro, Lampung views the reduction of time allocation for English subject as a weakness. As an English teacher, he personally disagrees with the 2013 curriculum since it makes the time allocation of English is decreased. Consequently, it automatically reduces English teachers' teaching hours in some schools including in his school, which will have financial consequences.

Rather different from Mr. DA, Mrs. DN who also comes rom Lampung, feels that implementing the 2013 curriculum especially in English teaching in senior high school is not very problematic. When asked about the barriers she faces, she said that actually there is no any serious obstacles since the curriculum does not insist the teacher to create or produce as it did in the previous school-based curriculum. Nevertheless, according to her, it is necessary to pay attention to the indicators that teachers must achieve. This is to emphasize that the main actor is teacher.

Although very small, this study has shown that more teachers have positive opinion towards the establishment of the 2013 curriculum. Nearly all participating teachers agree to implement the curriculum. However, all of them suggest that the curriculum should be improved in both its conceptual and technical aspects. In terms of the concept, the so-called "scientific approach" adopted in the 2013 curriculum is only briefly explained and therefore it should be further elaborated. Moreover, especially in teaching language, there has not been yet a method called scientific approach (Richard, 2014). In terms of the technical aspect, the idea of integrating different lessons promoted in the curriculum seems to be a big burden for the teachers. They do not have clear ideas on how various lessons could be integrated. For students, this is also a demanding activity because it is not easy to do. In addition, concerning the evaluation, daily individual assessment to all students required by the curriculum also make the teachers exhausted.

In summary, although the number of the teachers participating 
this research is very small, this at least can give a picture about how teachers perceive the 2013 curriculum. In addition, since they are teaching in the piloting schools, which are highly selected by the government, their opinions are considered reasonable and good to be one of considerations. Nearly all teachers interviewed in this study agree to the innovations offered by the new curriculum. Nevertheless, according to them, there are numerous challenges which have to be faced as explained in the following.

\section{Challenges and Opportunities}

According to the teachers, the principles established as the basis to develop 2013 English curriculum reveal some challenges and opportunities when it is implemented. The challenge, among others, is that the curriculum is a textbook-driven curriculum. This will possibly make the teachers not creative whereas they are expected to be creative and innovative. The next is that today, the curriculum has been officially declared to be used in teaching the first year students. However, there is no enough information, which of course will cause teachers to face confusion in implementing the curriculum in the teaching and learning process. Another challenge is the assessment, which is considered to be very demanding. Most of teachers argue that the scoring criteria are complicated and very time consuming. The other problem raised is the reduction of English subject hours, which causes the teachers' disappointment. Referring to the certification program launched by the government, all certified teachers have to teach 24 hours. When the time allocation for English is reduced, their teaching hours will automatically be reduced and this will have some financial consequences.

Nevertheless, despite the complexity of the 2013 curriculum, there are also some opportunities which can positively influence the teaching and learning practice. First of all, the concept of active learning, character building, and new paradigm of the curriculum 2013 is very relevant with the challenges faced by Indonesia. With this concept, it is expected that teachers are more creative and students enjoy the teaching and learning opportunities provided by the teachers. The next, even though very complex, the scoring criteria do not only focus on cognitive aspect, but also on personality aspect. Hence, the teachers can know their students more specifically. In this respect, students are evaluated not only based on what they know but also on the way they behave.

Furthermore, the scientific approach promoted in the new 
curriculum is expected to be able to encourage the development of students' critical thinking. When the teaching and learning covers the process of questioning, observing, collecting information, associating and communicating, students' critical thinking is likely to be more developed. Concerning the teaching English, this kind of process is hoped tp facilitate students in producing ideas particularly while speaking English. Furthermore, three learning models are adopted in this curriculum i.e. Discovery Learning, Problem-Based Learning, and ProjectBased Learning. The models are very appropriate to be employed in English classes. The mentioned opportunities can be seen as optimistic instruments to effectively implement the curriculum especially in English teaching.

In short, as has been the case of the previous curriculum, the 2013 curriculum also brings both challenges and opportunities. Teachers participating in this study agree to the ideas promoted in the 2013 curriculum. Although small in terms of the number, their opinion should be considered because they come from pilot schools selected by the government. Nevertheless, improvement is urgently needed.

\section{CONCLUSION AND SUGGESTION}

This paper aims at understanding teachers' voices on the implementation of the 2013 curriculum. The findings reveal that teachers positively perceive the changes offered in the new curriculum as an indication that the country is working towards the betterment of its education quality, following the continuously changing technology, science, and art. It is argued in the paper that teachers are the key actors of the curriculum implementation, and therefore they are expected to be open and innovate themselves in order to be able to provide better teacher and learning process. However, there are also some challenges that teachers face in implementing the curriculum. It is beneficial for both teachers and students when the government listen to teachers' voices and address the their challenges accordingly.

Referring to the aforementioned challenges, some suggestions are offered. Firstly, it is urgent for the government to better prepare the establishment of the new curriculum by providing sufficient training and supervision to teachers. Secondly, it is worth analyzing the time allocation for English subject so that English teachers are not afraid to loose their teaching time, which has financial consequence. 
Thirdly, teachers themselves should be more adaptive, creative and innovative to create good learning atmosphere. Finally, with respect to the assessment, scoring technique should to be simplified.

\section{REFERENCES}

Agustien, H.I.R. (2003) Setting up New Standards: A Preview of Indonesia's New Competencebased Curriculum. A Paper presented at the $51^{\text {st }}$ TEFLIN International Conference, Bandung, 21-23 October.

Cahyono, B.Y., \& Widiati, U. (2011). The Teaching of English as a Foreign Language in Indonesia. State University of Malang Press.

Celce-Murcia, M. (1991) Teaching English as a Second or Foreign Language. Boston: Heinle \& Heinle.

Dit. PSMP (Direktorat Pembinaan Sekolah Menengah Pertama/ Directorate of Junior High School Development) (2009). Perkembangan Kurikulum SMP (Junior High School Curriculum Development 0. Jakarta: Directorate of junior High School Development.
Dubin, F., \& Olshtain, E. (1986) Course Design: Developing Programs and Materials for Language Learning. Cambridge: Cambridge University Press.

Fraenkel, Jack R. Dan Norman E. Wallen. (2008) How to Design and Evaluate Research in Education. United States: Mc. Graw Hill.

Huda, N. (1999) Language Learning and Teaching: Issues and Trends. Malang: IKIP Malang Publisher.

Krahnke, K. (1987) Approaches to Syllabus Design in Foreign Language Teaching. Englewood Cliffs, NJ: Prentice-Hall.

Miles, B., M \& Huberman., A., M. (1994) Qualitative Data Enalysis. 2nd edition. Sage Pblication.

Murray, P. (1993). Curriculum Development and DesignAustralia: Allen and Unwin.

Tjokrosujoso, H., Antoro, S.D., \& Pantow, J.B.S. 2002. Curriculum and Material Development. Jakarta: Open University Publishing Center.

Yalden, j. (1987). The Communicative Syllabus. Englewood Cliffs: Prentice-Hall. 
Wachidah, S. (2013). 2013 English Curriculum. Paper presented at Seminar and Workshop on The 2013 English Curriculum, Bogor Ibn Khaldun University. 
Maulidia R.N \& Ahmad Madkur

134| IJEE, Vol. 1, No. 2, 2014 